\title{
Ajwa Seeds (Phoenix dactylifera L.) Suspension Exerted Antidiabetic and Antihyperlipidemic Effects Against Streptozotocin-Induced Diabetes in Rats by Downregulating Insulin Expression in the Pancreatic Beta Islets
}

\author{
Ahlam Abdulaziz Alahmadi*, Hessah Mohammed Banayah
}

Department of Biological Sciences, College of Science, King Abdulaziz University, Jeddah, Saudi Arabia.

${ }^{*}$ Correspondence to: Ahlam Abdulaziz Alahmadi (E-mail: aahmadi1000@hotmail.com)

(Submitted: 18 April 2021 - Revised version received: 29 April 2021 - Accepted: 11 May 2021 - Published online: 26 August 2021)

\begin{abstract}
Objectives This study investigated the antidiabetic and antihyperlipidemic effects of the powdered seeds of Ajwa Al-Madina in streptozotocin (STZ)-induced diabetes in rats. Besides investigating the possible underlying mechanisms.

Methods Rats were assigned to one of six groups $(n=5)$ as follows: normal control, vehicle control, Ajwa seeds control, diabetic control, Diabetic + Metformin, and Diabetic + Ajwa seeds. Metformin and Ajwa seeds were injected into rats orally via oral gavage 6 days/week along 4 weeks period.

Results Ajwa seeds decreased fasting serum glucose, increased fasting serum insulin and decreased fasting serum triglycerides cholesterol, low-density lipoprotein, and increased fasting serum high-density lipoprotein. Besides, it upregulated insulin protein immunoexpression in the beta cells of Langerhans islets. Ajwa seed also preserved the normal histological structure of the pancreatic beta cells tissue.

Conclusion Ajwa seeds produced significant hypoglycemic and hypolipidemic effects in diabetic rats mainly through enhancement of insulin secretion. The plant is a promising adjunctive therapy in diabetes mellitus treatment.

Keywords Ajwa seeds, glucose, insulin, histopathology, lipids, immunoexpression
\end{abstract}

\section{Introduction}

Diabetes mellitus (DM) is one of the world's fastest-growing health issues in the twenty-first century. It is one of the leading causes of death worldwide. if not treated properly, it can cause chronic health problems, especially cardiovascular, renal, and nerve complications. ${ }^{1}$ According to the International Diabetes Federation (IDF), the global prevalence of DM is projected to rise from 425 million patients in 2017 to 629 million in 2045 . In the Middle East, DM claimed the lives of 38.7 million people between the ages of 20 and 79 years in $2017 .{ }^{2,3} \mathrm{DM}$ is one of the most prevalent health problems in Saudi Arabia (SA). ${ }^{4} \mathrm{DM}$ has also increased tenfold in SA over the last three decades. ${ }^{5}$ While there are several oral drugs available to treat $\mathrm{DM}$, the majority of them are ineffective at preventing serious complications, regulating blood glucose levels, and are associated with numerous side effects.

In the last century, herbal medicines have gained popularity. Before the introduction of medications, traditional healers used herbal products to cure DM. A plant extract is a mixture of organic chemicals derived from some portion of the plant. As a result, they are healthy since they are organic and thus less dangerous and have fewer adverse reactions. ${ }^{7,8}$ Many fruits' seeds are used in traditional and herbal medicine to prevent diseases, relieve stress, and minimize side effects. ${ }^{9}$

Dates (Phoenix dactylifera L., family Arecaceae) are a common fruit in the Arab World. It is regarded as a major nutritional and economic product. ${ }^{10}$ In Egypt, SA, and other Middle East countries, it is the most important crop. ${ }^{11}$ Phoenix dactylifera ( $P h$. dactylifera) seeds are normally discarded by the fruit industry as byproducts. These seeds have often been roasted, ground, and used as a caffeine-free coffee substitute, either pure or mixed with coffee, as well as animal feed. ${ }^{12}$ The various parts of $P h$. dactylifera are popularly used to manage a variety of ailments, including neurological diseases, memory deterioration, paralysis, hyperthermia, and coma. ${ }^{13}$ Date fruits and seeds, in the form of powder, pulp, and infusion, are commonly used in research to treat atherosclerosis, malignancy, asthenia, pulmonary ailments, and throat infections. Date fruits and seeds are also used as an antidiarrheic, hypoglycemic, expectorant, tonic, aphrodisiac, and mouthwash. ${ }^{14}$

Ajwa is a form of the date that is only grown in SA/ Al-Madinah Al-Munawara and has a high medicinal value. The health benefits of Ajwa dates have been recorded in hadith, with Saud (R.A) narrating, "If anyone takes seven Ajwa dates in the morning, neither magic nor poison can harm him that day". ${ }^{11}$ Ajwa date seed extracts were found to have an antihyperglycemic activity in laboratory animals in several recent studies. ${ }^{15,16}$ However, the mechanism underlying this effect remains unknown and requires further investigation and evidence.

This study aims to examine if the powdered seeds of Ajwa Al-Madina have a therapeutic impact on DM induced by streptozotocin (STZ) in rats, and if so, what the mechanism is.

\section{Materials and Methods Drugs and Chemicals}

STZ was obtained from Sigma-Aldrich, USA. Metformin (Glucophage, $500 \mathrm{mg}$, Merck Santé, France) from Alnahdi pharmacy, SA. Ajwa seeds were gathered from Ajwa dates, Oasis Lina, Al-Madinah Al-Munawara, SA.

\section{Ajwa Seeds Aqueous Suspension}

The seeds were separated from the fleshes, and the deposit was cleaned. Seeds were air-dried at ambient temperature for 15-21 days. The dried seeds were ground into a fine powder using a hammer mill. One-gram Ajwa seeds powder was mixed with $10 \mathrm{ml}$ Tween-80 to make seeds suspension (Figure 1). 
A

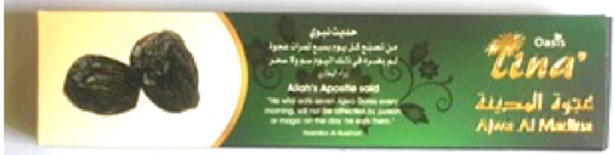

B

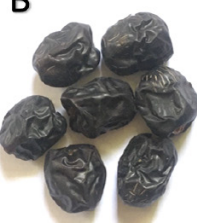

C

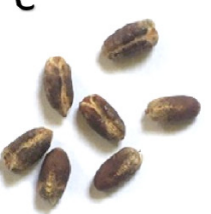

D

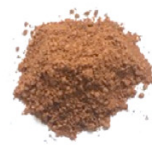

Fig. 1 Ajwa dates and Ajwa seeds. A and B: Ajwa date purchased from the Oasis Lina (dates company), C: seeds removed from the fruit and washed to remove the residues, D: ground seeds (fine powder).

\section{Determination of Ajwa Seeds Volatile Constituents}

Solid-phase extraction-gas chromatography/mass spectrometry (SPE-GC/MS) analysis was performed based on the recently published method of ${ }^{17}$ at the Analytical Chemistry Unit, Assiut University, Assiut, Egypt.

\section{Animals}

Thirty adult Wistar rats (150 g - 250 g body weight) were obtained from King Fahad Research Centre, King Abdulaziz University (KAU), Jeddah, SA. The rats were maintained for one week under the standard laboratory circumstances of temperature, humidity, and light/dark cycle (12:12 h). During the adaptation period, the rats could drink and eat free.

\section{Ethical Approval}

The study design was accepted by the Biomedical Ethics Research Committee (registration number: 346-19), College of Medicine, KAU, Jeddah, SA.

\section{Induction of Diabetes}

The rats were given a single injection of STZ ( $35 \mathrm{mg} / \mathrm{kg})$ intraperitoneally. ${ }^{18}$ Fasting blood glucose levels were measured using the ACCU-CHEK apparatus after seven days. Glucose levels higher than $200 \mathrm{mg} / \mathrm{dl}$ were identified as diabetes rats ${ }^{19}$ (Figure 2).

\section{Experimental Groups}

Rats were assigned to one of six groups $(n=5)$ as follows:

1- Normal control (NC) group: rats received $2 \mathrm{ml}$ distilled water.

2- Vehicle control (VC) group: rats received $2 \mathrm{ml}$ tween 80 .

3- Ajwa seeds control (AC) group: rats received $2 \mathrm{ml}$ Ajwa seeds suspension $(1 \mathrm{~g} / \mathrm{kg}){ }^{20}$

4- Diabetic control (DC) group: diabetic induced rats received $2 \mathrm{ml}$ distilled water.

5 - Diabetic + Metformin (DM) group: diabetic rats received $2 \mathrm{ml}$ metformin solution $(150 \mathrm{mg} / \mathrm{kg}){ }^{2}$

6- Diabetic + Ajwa seeds (DA) group: diabetic rats received $2 \mathrm{ml}$ Ajwa seeds suspension $(1 \mathrm{~g} / \mathrm{kg})$.
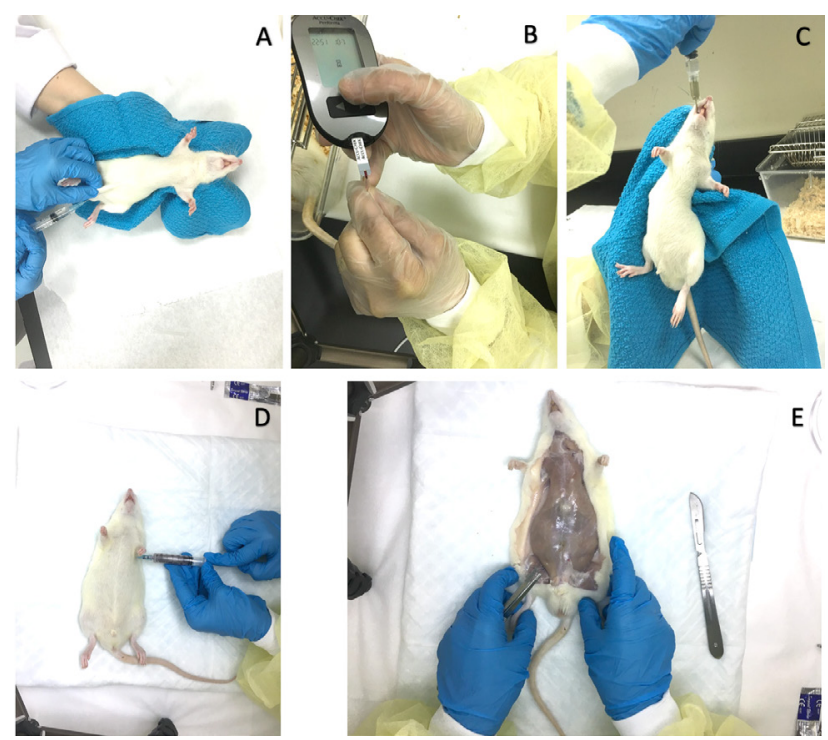

Fig. 2 Diabetes induction, dose administration, and sample collection. A: Induction of diabetes in rats using an intraperitoneal injection of STZ, B: Determine blood glucose levels using ACCU-CHEK, C: treatment the rats using oral gavage, $D:$ a collection of the blood from the heart, E: dissection the rats.

Metformin and Ajwa seeds were injected into rats orally via oral gavage 6 days/week along 4 weeks period (Figure 2).

\section{Obtaining Samples}

Four weeks after treatment protocol administration, rats were starved overnight and were sedated with ether for blood withdrawal from the heart (heart puncture technique). Blood samples were centrifuged at $3500 \mathrm{rpm}$ for 15 minutes under cooling conditions then the sera were separated and kept frozen at $-80^{\circ} \mathrm{C}$. After that, the rats were killed and dissected, and all pancreases were excised, washed in 0.9 percent saline, and stored either frozen at $-80^{\circ} \mathrm{C}$ or in a $10 \%$ buffered formalin solution (Figure 2).

\section{Assessment of Fasting Serum Glucose}

Fasting serum glucose concentrations were determined using Diagnostics Reactivos GPL, Barcelona, Spain colorimetric kit according to the brochure instructions.

\section{Assessment of Fasting Serum Insulin}

Fasting serum insulin concentrations were determined using Immunospec, CA ELISA kit according to the brochure instructions.

\section{Assessment of Fasting Serum Lipid Profile}

The fully automated technique using ELISA, (Dynex) was used to measure fasting serum lipid profile (triglyceride (TG), cholesterol (CHOL), low-density lipoprotein (LDL), and high-density lipoprotein (HDL)) according to the instruction brochure accompanying the kits.

\section{Histopathological Study (Hematoxylin and Eosin (H \& E) Staining)}

Formalin-fixed pancreases were processed in the histology lab, pathology department, King Abdulaziz University, SA, and were stained with $\mathrm{H} \& \mathrm{E}$. The sections were then examined under the light microscope by a blind pathologist. 


\section{Immunohistochemical Study (Insulin and Nuclear Factor kappa Beta (NF-KB)}

For determining the presence and secretion of insulin in pancreatic beta cells, the sections were stained immunohistochemically for insulin using. ${ }^{22}$ For determining the inflammatory cells in the sections, the pancreas sections were stained immunohistochemically for NF- $\kappa \mathrm{B} .{ }^{23}$

An immunoperoxidase (peroxidase/anti peroxidase, $\mathrm{PAP}$ ) protocol was utilized to stain the pancreas segments for insulin and NF- $\kappa \mathrm{B}$ proteins. The antibodies (bought from Lab Vision, Fremont, CA) were diluted in 1:200 dilution. The segments were analyzed and photted, utilizing light microscopy.

\section{Data Analysis}

The averages \pm standard errors were used to display the data. The data were analyzed statistically using a one-way analysis of variance (ANOVA) and Tukey's post-hoc test. A $P$-value of less than 0.05 was used as the significant level. SPSS for Windows, version 22, Armonk, NY was used to conduct the data analysis.

\section{Results}

\section{Ajwa Seeds Volatile Constituents}

Table 1 showed of the volatile active constituents of Ajwa seeds powder.

\section{Effect of Ajwa Seed and Metformin on Fasting Serum Glucose Measured in Control and Diabetic Rats}

There were no significant differences between the serum glucose concentration of the three control groups (NC, VC, and $\mathrm{AC})$. The DC group showed a significantly increased serum glucose concentration compared to the NC group $(P<0.001)$. Treatment of DC group with metformin and Ajwa seed suspension significantly decreased serum glucose concentration compared to DC group $(P<0.001)$. Ajwa seed suspension significantly decreased serum glucose concentration compared to the DM group $(P<0.05)$ (Fig. 3).

\section{Effect of Ajwa Seed and Metformin on Fasting Serum Insulin Measured in Control and Diabetic Rats}

The DC group showed a significantly decreased serum insulin concentration compared to the NC group $(P<0.001)$. Treatment of DC group with metformin and Ajwa seed suspension significantly increased serum glucose concentration compared to DC group $(P<0.001)$. Ajwa seed suspension significantly increased serum glucose concentration compared to the DM group $(P<0.001)$ (Fig. 4).

\section{Effect of Ajwa Seed and Metformin on Serum Lipids Profile Measured in Control and Diabetic Rats}

There were no significant differences between various serum lipids concentrations of the three control groups (NC, VC, and $\mathrm{AC}$ ). The DC group showed significantly increased serum TG, $\mathrm{CHOL}$, and LDL concentrations compared to the NC group $(P<0.001)$. On the other hand, serum LDH concentration was

\begin{tabular}{|c|c|}
\hline Analyte/Parameter & Value \\
\hline Octadecanoic acid & $1.158 \%$ \\
\hline 2,3Dehydro-3-hydroxy-2-4 dimethylamine & $0.219 \%$ \\
\hline N-(1-Methyl Cyclopropyl) urea & $0.116 \%$ \\
\hline Cyclolanost-24-en-3-ol3)9- 19 Beta( & $6.226 \%$ \\
\hline 2,2-Dimethy-Itetrahydrofuran & $2.568 \%$ \\
\hline 2,6-Bis (1,1-dimethyllethyl)-4-methyl-Phenol & $0.347 \%$ \\
\hline Amine, 6-methixy-1H-Purine & $0.766 \%$ \\
\hline Propenoic acid, 1-methylundecyl ester & $0.035 \%$ \\
\hline 3-(4-Aminobutyl) piperidine & $0.007 \%$ \\
\hline 5-Htdroxy-2,4 (1H,3H)-Pyrimidinedione & $0.164 \%$ \\
\hline 9-Hexadecenoic acid, octadecyl ester & $0.142 \%$ \\
\hline 9-Octadecenoic acid (E) & $0.5334 \%$ \\
\hline 9- Octadecenoic acid (Z)-, tetradecyl ester & $0.222 \%$ \\
\hline ALPHA -TERPINOENE & $0.058 \%$ \\
\hline Androst-5, 15-dien-3ol acetate & $0.578 \%$ \\
\hline Benzo[F]quinoline & $0.410 \%$ \\
\hline cis-13-Octadecenoic acid & $1.666 \%$ \\
\hline Delta.9-cis-Oleic acid & $0.457 \%$ \\
\hline Di-tert-Butylphenol & $0.099 \%$ \\
\hline Dodecanoic acid & $3.746 \%$ \\
\hline FARNESYL ACETATE 3 & $0.506 \%$ \\
\hline Gamma. -Sitosterol & $2.630 \%$ \\
\hline Glycyl-dl-alanine & $0.008 \%$ \\
\hline Hexanedioic acid, bis (2-ethylhexyl) ester & $0.181 \%$ \\
\hline i-Propyl 9-octadecenate & $0.378 \%$ \\
\hline $\begin{array}{l}\mathrm{N} \text {-[Amino(imino)methyl]-3-(2,4-dihydroxy-5- } \\
\text { pyrimidinyl) Alanine }\end{array}$ & $0.006 \%$ \\
\hline N-Butyl-N-nitrosourea & $0.054 \%$ \\
\hline$n$-Hexadecoic acid & $2.102 \%$ \\
\hline n-propyl 11-octadecenoate & $0.101 \%$ \\
\hline Octadecenoic acid, 1, 2, 3-propanetriyl ester & $0.050 \%$ \\
\hline Oleic acid & $0.614 \%$ \\
\hline Pentafluoro propionic acid, 4-hexadecyl ester & $0.477 \%$ \\
\hline Phytane & $0.249 \%$ \\
\hline Squalene & $0.434 \%$ \\
\hline Stigmastan-3,5-diene & $1.348 \%$ \\
\hline Tera decanoic acid & $2.258 \%$ \\
\hline Terahydrofurfuryl alcohol & $0.948 \%$ \\
\hline
\end{tabular}

decreased in the DC group compared to the NC group $(P<$ 0.001). Treatment of DC group with metformin and Ajwa seed suspension significantly decreased serum TG, CHOL, and LDL concentrations compared to DC group $(P<0.001)$. Furthermore, treatment of DC group with metformin and Ajwa seed suspension significantly increased serum HDL concentration compared to the DC group $(P<0.001)$. Ajwa seed suspension significantly decreased serum LDL concentration compared to the DM group $(P<0.001)$ (Table 2$)$. 


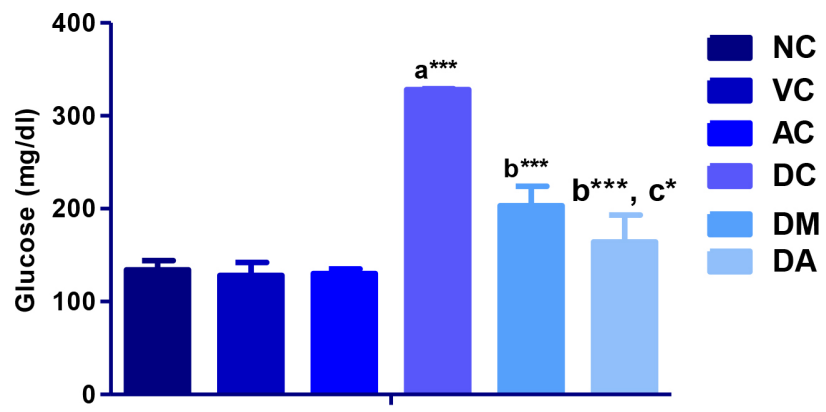

Groups

Fig. 3 Effect of Ajwa seed and metformin on fasting serum glucose measured in control and diabetic rats. Data were displayed as averages \pm standard errors. ${ }^{\text {adisplayed significant }}$ difference compared to NC. 'bisplayed a significant difference compared to DC. 'displayed a significant difference compared to DM. ${ }^{* * *}$ displayed significant difference at $P<0.001$. "displayed significant difference at $P<0.05$.

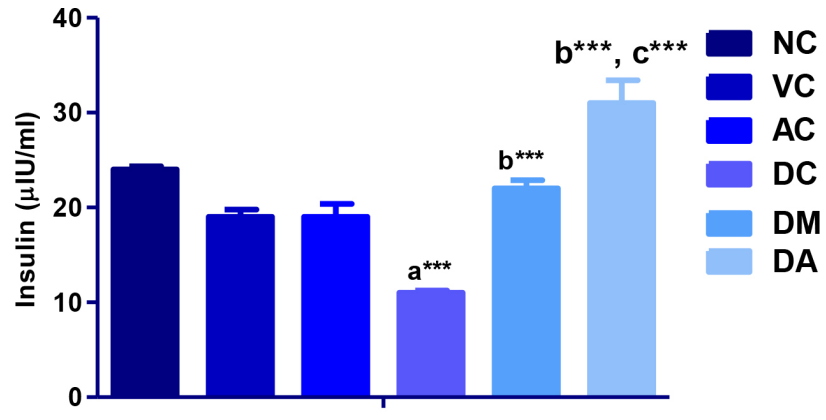

Groups

Fig. 4 Effect of Ajwa seed and metformin on fasting serum insulin measured in control and diabetic rats. Data were displayed as averages \pm standard errors. a displayed significant difference compared to NC. 'bisplayed a significant difference compared to DC. 'displayed a significant difference compared to DM. ${ }^{* * *}$ displayed significant difference at $P<0.001$.

Table 2. Effect of Ajwa seed and metformin on serum lipid profile measured in control and diabetic rats

\begin{tabular}{|c|c|c|c|c|}
\hline Groups & TG (mg/dl) & CHOL (mg/dl) & LDL (mg/dl) & $\mathrm{HDL}(\mathrm{mg} / \mathrm{dl})$ \\
\hline NC & $101 \pm 1.4$ & $117 \pm 2.9$ & $29 \pm 0.27$ & $21 \pm 0.78$ \\
\hline VC & $97 \pm 3.2$ & $125 \pm 0.34$ & $29 \pm 0.92$ & $17 \pm 1.9$ \\
\hline$A C$ & $102 \pm 0.5$ & $125 \pm 0.73^{\mathrm{a}}$ & $27 \pm 1.2$ & $19 \pm 1.3$ \\
\hline DC & $124 \pm 2.9^{9^{* * *}}$ & $144 \pm 1.7^{\mathrm{a}^{* * *}}$ & $43 \pm 0.63^{a^{2 * x}}$ & $8 \pm 0.15^{a^{* * * x}}$ \\
\hline DM & $105 \pm 1.3^{b * * *}$ & $127 \pm 2.1^{b^{* * *}}$ & $36 \pm 0.77^{b^{* * *}}$ & $13 \pm 0.1^{b^{* * *}}$ \\
\hline DA & $101 \pm 1.2^{2 * *+*}$ & $132 \pm 2.2^{b^{k+k x}}$ & $29 \pm 1.6^{b^{* * *}, c^{* * *}}$ & $13 \pm 0.2^{b^{* * *}}$ \\
\hline
\end{tabular}

Data were displayed as averages \pm standard errors. ${ }^{2}$ displayed significant difference compared to NC. bdisplayed a significant difference compared to DC. cdisplayed a significant difference compared to DM. "*" displayed significant difference at $P<0.001$

\section{Effect of Ajwa Seed and Metformin on Histopathological Changes in Control and Diabetic Rats Pancreas}

As shown in Fig. 5 islets of Langerhans of NC pancreas revealed normal morphology. Also, there were normal density and distribution of different cell population. The Beta cells were apparently larger in size and were most central in
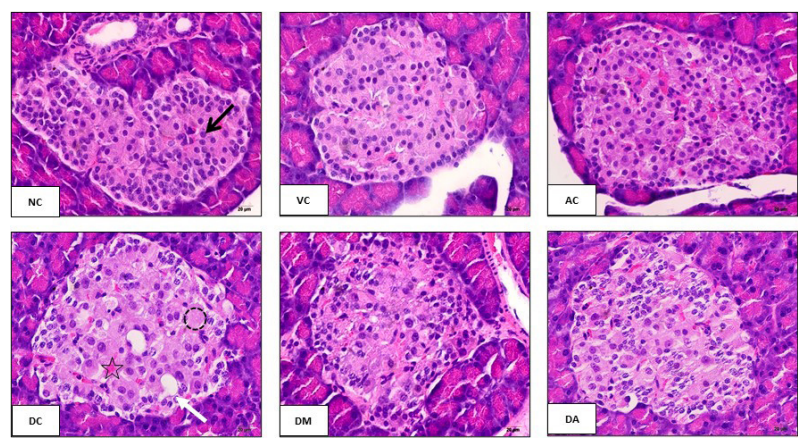

Fig. 5 Effect of Ajwa seed and metformin on histopathological changes observed in control and diabetic rats' pancreas. Sections from rat' pancreases were stained with $\mathrm{H} \& \mathrm{E}$ and photographed at high (x600) magnification. NC: Normal control showed normal islets with normal density and distribution of different cell populations. Beta cells are most central in position, showed the equal size and centrally located nuclei (black arrow). Also, blood capillaries between the cells are thin-walled and compressed. VC: Vehicle control showed no alteration in the normal cell population of Langerhans islets. Also, in AC: Ajwa seed control showed normal morphology islets component and no alteration compared to control. DC: Diabetic control showed decreased nuclear density with numerous regions that completely lack nuclei (necrotic region). The islets showed a large area of hemorrhage (star). Some cells had vacuolated cytoplasm (white arrows). DM: Diabetic + metformin showed preservation of normal islet morphology and cell density. DA: Diabetic + Ajwa seed showed an apparent increase in the size of central cells and more preservation in the islets of Langerhans. Notice: The potential decrease in necrotic cells in DM and DA group.

position, their nuclei were lightly stained (active) and centrally located. Blood capillaries between the cells were thin-walled and compressed. In VC and $\mathrm{AC}$ groups there was no alteration in the normal cell density of islets cells. In the DC group, the islets showed central cells with a larger size, homogenous acidophilic cytoplasm, degenerated small, and even lost nuclei. In the DM group preservation of normal islets morphology, and cell density was observed. The apparent increase in the size of central cells is evident. More evident preservation was observed in the islets of the DA group.

\section{Effect of Ajwa Seeds on Pancreatic Immunoexpression of Insulin Observed in Control and Diabetic Rats' Pancreas}

As shown in Fig. 6 islets of Langerhans of NC pancreas showed highly positive staining for insulin which was observed in a large population of centrally located cells in Langerhans islets. In VC and AC groups no alteration was observed in immunostaining for insulin compared to the NC group. In the DC group, a significant decrease in positive insulin-immunostained cells was observed where they apparently looked enlarged compared to those of the NC. In DM and DA treated groups a significant increase of insulinimmunostained cells was observed compared to the DC group.

\section{Discussion}

Diabetes mellitus is a long-term condition that is linked to several metabolic problems. Hyperglycemia, or high blood glucose, is the most prevalent sign of diabetes. The underlying causes of diabetes are either a lack of insulin production or insulin resistance or both. ${ }^{24}$ Chemical medicines have been 

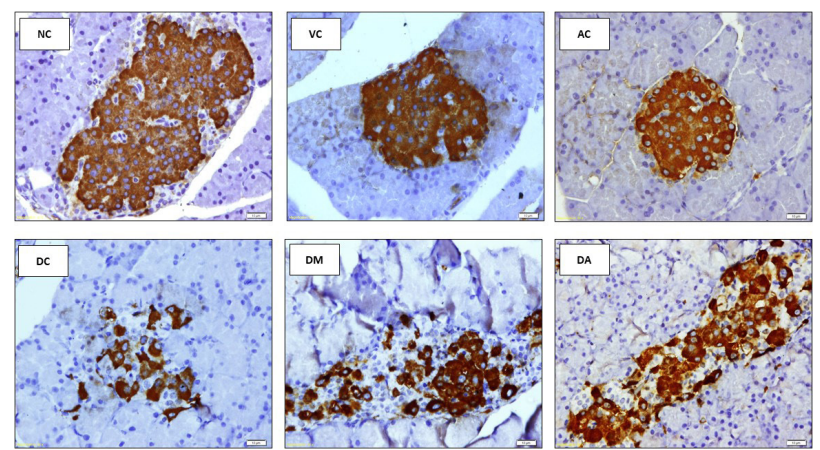

Fig. 6 Effect of Ajwa seeds on pancreatic immunoexpression of insulin observed in control and diabetic rats' pancreas. Sections from rats' pancreases were immuno-stained for insulin. And photographed at high (x600) magnification. NC: Normal control, showed highly immunopositive staining for insulin in most centrally located beta-cells. VC: Vehicle control showed also a large number of beta cells highly immune stained for insulin. AC: Ajwa seeds control showed immunostaining for insulin more or less like NC pancreas. DC: Diabetic control showed a marked decreased in the number of immune positive stained cells for insulin. DM: Diabetic + metformin showed a potential increase of immune stained for insulin size of cells. Notice, the apparent increase in the size of stained cells. DA: Diabetic + Ajwa seeds showed marked preservation of immune positive stained cells for insulin. Notice there is also an apparent increase in cells size.

shown in studies to be ineffective in treating DM since it does not entirely control glucose levels and has numerous negative effects. In this regard, research on plant species has demonstrated their usefulness in diabetes treatment, with toxicological tests proving that they are the safest choice. ${ }^{25}$

This study aimed to confirm the therapeutic impact of the powdered seeds of Ajwa Al-Madina on DM induced by STZ in rats. Ajwa seeds demonstrated a significant increase in insulin level, which led to a considerable decrease in blood glucose levels when compared to untreated diabetic rats. Hence, the glucose level returned to a more normal range in Ajwa seeds group. In addition, Ajwa seeds significantly decreased the blood glucose level than metformin (the reference antidiabetic drug). The current findings are consistent with those of a previous study, which found that Saudi date seeds extract incorporating Ajwa seeds had a hypoglycemic and antidiabetic impact in the STZ rat model. ${ }^{15,16}$ Additionally, hypoglycemic effects were reported in many types of Phoenixes dactylifera L. seeds and flesh such as Sukkari date seeds, ${ }^{16}$ Hayani, ${ }^{26}$ and other types. ${ }^{27}$ Similar results hypothesized that
Ajwa date seeds stimulate insulin secretion from existing $\beta$-cells, consequently, the blood glucose levels decreased. In diabetic rats treated with date seed extract, the data revealed a significant elevation in insulin concentration, which could explain the significant decrease in mean blood glucose concentration noticed in those rats. ${ }^{28}$ Furthermore, a prior study backs up the effectiveness of date seed extract in controlling hyperglycemia. ${ }^{29}$

Histological analysis of islets of Langerhans employing both routine $\mathrm{H} \& \mathrm{E}$ staining and insulin immunostaining was utilized to show if Ajwa seeds function by modulating the structure and insulin content of beta cells. In the present study, induction of diabetes was associated with many beta cells morphology alterations and degenerative changes including vacuolation, cytoplasmic hyalinization, and degraded or missing nuclei. Similar findings were also reported by ${ }^{22,24}$ The results of this study also showed that the administration of Ajwa seeds was found to restore the normal structure of $\beta$-cells islets and the immunostaining for insulin. The current results revealed that Ajwa seeds increase insulin secretion from the islets beta cells. While a previous study showed that date seed extract exerts its hypoglycemic impact on type 1 diabetic mice by enhancement of endogenous insulin production via extraislet sources, according to. ${ }^{28}$

Ajwa seeds produced a significant decrease in all harmful lipids including TF, CHOL, and LDL, where it significantly increases the useful lipid, HDL. These findings are consistent with the recent results which concluded that Ajwa date pit ameliorated hyperglycemia and hypercholesterolemia associated with obesity in experimental animals. The antioxidants impact of the pits may clarify the observed lipid and glucoselowering action..$^{30}$ Similarly, many previous studies reported the antihyperlipidemic activity of dates pits and suggesting that the polyphenols' active constituents of the pits may exert both antioxidants and inhibiting the pancreatic lipase activity resulting in decreasing gastrointestinal lipid absorption and hence lowered the blood lipids. ${ }^{31-33}$

\section{Conclusion}

Ajwa seeds possess antidiabetic and antihyperlipidemic effects against STZ-induced diabetes in rats. The preservation of beta cells in the pancreas and induction of insulin secretion is the most likely mechanism by which Ajwa seeds exerted their antidiabetic action in this model. As a result, Ajwa seeds could be used in conjunction with dietary and pharmacological therapy to improve diabetes control.

\section{References}

1. Fan, W. 2017. Epidemiology in diabetes mellitus and cardiovascular disease. Cardiovasc Endocrinol, 6(1), 8-16, https://doi.org/10.1097/ XCE.0000000000000116.

2. Meo, S., Sheikh, S., Sattar, K., Akram, A., Hassan, A., Meo, A., Usmani, A., Qalbani, E. \& Ullah, A. 2019. Prevalence of type 2 diabetes mellitus among men in the middle east: a retrospective study. Am J Mens Health, 13(3), 1557988319848577, https://doi.org/10.1177/1557988319848577.

3. Cho, N.H., Shaw, J.E., Karuranga, S., Huang, Y., da Rocha Fernandes, J.D., Ohlrogge, A.W. \& Malanda, B. 2018. IDF Diabetes Atlas: Global estimates of diabetes prevalence for 2017 and projections for 2045. Diabetes Res Clin Pract, 138, 271-281, https://doi.org/10.1016/j.diabres.2018.02.023.

4. Alotaibi, A., Perry, L., Gholizadeh, L. \& Al-Ganmi, A. 2017. Incidence and prevalence rates of diabetes mellitus in Saudi Arabia: An overview. J Epidemiol Glob Health, 7(4), 211-218, https://doi.org/10.1016/j. jegh.2017.10.001.

5. Dawish, M. \& Robert, A. 2020. Diabetes mellitus in saudi arabia challenges and possible solutions. In: Handbook of Healthcare in the Arab World, Springer, Cham, 1-18.

6. Raz, I. 2013. Guideline approach to therapy in patients with newly diagnosed type 2 diabetes. Diabetes Care, 36(SUPPL.2), S139-S144, https:// doi.org/10.2337/deS13-2035

7. Kasole, R., Martin, H. \& Kimiywe, J. 2019. Traditional medicine and its role in the management of diabetes mellitus: patients and herbalists perspectives. Evidence-based Complement Altern Med, 2019, 2835691, https://doi. org/10.1155/2019/2835691.

8. Amit Koparde, A., Chandrashekar Doijad, R. \& Shripal Magdum, C. 2019. Natural products in drug discovery. Pharmacogn - Med Plants, https://doi. org/10.5772/intechopen.82860.

9. Melek, F., Saleh, D., Medhat, A., Farrag, A., Ghaly, N. \& Baraka, S. 2019. Antidiabetic and antioxidant activities of Phoenix dactylifera I. seed extract 
in streptozotocin-induced diabetic rats. Malaysian J Biochem Mol Biol, 22(1), 53-59.

10. Ghnimi, S., Umer, S., Karim, A. \& Kamal-Eldin, A. 2017. Date fruit (Phoenix dactylifera L.): An underutilized food seeking industrial valorization. NFS J, 6, 1-10, https://doi.org/10.1016/j.nfs.2016.12.001.

11. Rahmani, A., Aly, S., Ali, H., Babiker, A., Suikar, S. \& Khan, A. 2014. Therapeutic effects of date fruits (Phoenix dactylifera) in the prevention of diseases via modulation of anti-inflammatory, anti-oxidant and anti-tumour activity. Int J Clin Exp Med, 7(3), 483-491.

12. Venkatachalam, C. \& Sengottian, M. 2016. Study on roasted date seed non caffeinated coffee powder as a promising alternative. Asian $J$ Res Soc Sci Humanit, 6(6), 1387-1394, https://doi.org/10.5958/22497315.2016.00292.6.

13. Sani, I., Hidayah, N., Bakar, A., Adzim, M., Rohin, K., Suleiman, I., Umar, M. \& Mohamad, N. 2015. Phoenix dactylifera Linn as a potential novel antioxidant in treating major opioid toxicity. J Appl Pharm Sci, 5(08), 167-172, https://doi.org/10.7324/JAPS.2015.50826.

14. Bnouham, M., Ziyyat, A., Mekhfi, H., Tahri, A. \& Legssyer, A. 2006. Medicinal plants with potential antidiabetic activity-A review of ten years of herbal medicine research (1990-2000). Journal of diabetes \& metabolism, 14, 1-25.

15. Sarfraz, M., Khaliq, T., Khan, J. \& Aslam, B. 2017. Effect of aqueous extract of black pepper and ajwa seed on liver enzymes in alloxan-induced diabetic Wister albino rats. Saudi Pharm J, 25(4), 449-452, https://doi.org/10.1016/j. jsps.2017.04.004.

16. Hasan, M. \& Mohieldein, A. 2016. In vivo evaluation of anti diabetic, hypolipidemic, antioxidative activities of saudi date seed extract on streptozotocin induced diabetic rats. J Clin Diagnostic Res, 10(3), FF06-FF12, https://doi.org/10.7860/JCDR/2016/16879.7419.

17. Neamatallah, T., El-Shitany, N., Abbas, A., Ali, S. \& Eid, B. 2018. Honey protects against cisplatin-induced hepatic and renal toxicity through inhibition of NF-kB-mediated COX-2 expression and the oxidative stress dependent BAX/ Bcl-2/caspase-3 apoptotic pathway. Food Funct, 9(7), 3743-3754, https:// doi.org/10.1039/C8FO00653A

18. Meng, X.M., Ma, X.X., Tian, Y.L., Jiang, Q., Wang, L.L., Shi, R., Ding, L. \& Pang, S.G. 2017. Metformin improves the glucose and lipid metabolism via influencing the level of serum total bile acids in rats with streptozotocininduced type 2 diabetes mellitus. Eur Rev Med Pharmacol Sci, 21(9), 2232-2237.

19. Zhang, M., Lv, X., Li, J., Xu, Z. \& Chen, L. 2008. The characterization of high-fat diet and multiple low-dose streptozotocin induced type 2 diabetes rat model. Exp Diabetes Res, 2008, 704045, https://doi. org/10.1155/2008/704045.

20. Khan, F., Khan, T., Kalamegam, G., Pushparaj, P., Chaudhary, A., Abuzenadah, A., Kumosani, T., Barbour, E. \& Al-Qahtani, M. 2017. Anti-cancer effects of Ajwa dates (Phoenix dactylifera L.) in diethylnitrosamine induced hepatocellular carcinoma in Wistar rats. BMC Complement Altern Med, 17(1), 418, https://doi.org/10.1186/s12906-017-1926-6.
21. El-Sayed, M., Al-Massarani, S., El Gamal, A., El-Shaibany, A. \& Al-Mahbashi, H. 2020. Mechanism of antidiabetic effects of Plicosepalus Acaciae flower in streptozotocin-induced type 2 diabetic rats, as complementary and alternative therapy. BMC Complement Med Ther, 20(1), 290, https://doi. org/10.1186/s12906-020-03087-z.

22. Samaha, M., Said, E. \& Salem, H. 2019. Nilotinib enhances $\beta$-islets integrity and secretory functions in a rat model of STZ-induced diabetes mellitus. Eur J Pharmacol, 860, 172569, https://doi.org/10.1016/J.EJPHAR.2019.172569.

23. Ingaramo, P., Ronco, M., Francés, D., Monti, J., Pisani, G., Ceballos, M., Galleano, M., Carrillo, M. \& Carnovale, C. 2011. Tumor necrosis factor alpha pathways develops liver apoptosis in type 1 diabetes mellitus. Mol Immunol, 48(12-13), 1397-1407, https://doi.org/10.1016/J. MOLIMM.2011.03.015.

24. Al-Thobaiti, S. \& Abu Zeid, I. 2019. Antidiabetic potential of balanites aegyptiaca kernel, flesh and their combination against streptozotocininduced hyperglycemia in male rats Trop J Pharm Res, 18(2), 263-271, https://doi.org/10.4314/tjpr.v18i2.7.

25. Putta, S., Yarla, N., Kilari, E., Surekha, C., Aliev, G., Divakara, M., Santosh, M., Ramu, R., Zameer, F., Mn, N., Chintala, R., Rao, P., Shiralgi, Y. \& Dhananjaya, B. 2016. Therapeutic potentials of triterpenes in diabetes and its associated complications. Curr Top Med Chem, 16(23), 2532-2542, https://doi.org/10.2 174/1568026616666160414123343.

26. Abdelaziz, D. \& Ali, S. 2014. The protective effect of Phoenix dactylifera L. seeds against CCl4-induced hepatotoxicity in rats. J Ethnopharmacol, 155(1), 736-743, https://doi.org/10.1016/J.JEP.2014.06.026.

27. El-Mousalamy, A., Hussein, A., Abdelaziz, A., Shaker, G. \& Mahmoud, S. 2016. Aqueous and methanolic extracts of palm date seeds and fruits (Phoenix dactylifera) protects against diabetic nephropathy in type II diabetic rats. Biochem Physiol Open Access, 2016(5), 205, https://doi.org/10.4172/21689652.1000205 .

28. El-Fouhil, A., Ahmed, A. \& Darwish, H. 2013. Hypoglycemic effect of an extract from date seeds on diabetic rats. Saudi Med J, 31(7), 747-751.

29. El Fouhil, A., Ahmed, A., Darwish, H., Atteya, M. \& Al-Roalle, A. 2011. An extract from date seeds having a hypoglycemic effect is it safe to use? Saudi Med J, 32(8), 791-796.

30. Aftab, A., Muhammad Umair, A., Farhan, S. \& Tabussam, T. 2019. Exploring the role of date pit based drinks against hyperglycemia and hypercholesterolemia. Prog Nutr, 21(1-S), 307-320, https://doi. org/10.23751/PN.V2111-S.6194.

31. Kawaguchi, K., Mizuno, T., Aida, K. \& Uchino, K. 1997. Hesperidin as an inhibitor of lipases from porcine pancreas and Pseudomonas. Biosci Biotechnol Biochem, 61(1), 102-104, https://doi.org/10.1271/BBB.61.102.

32. Halaby, M. 2014. Potential effect of date pits fortified bread on diabetic rats. Int J Nutr Food Sci, 3(2), 49, https://doi.org/10.11648/j.jinfs.20140302.16.

33. Habib, H. \& Ibrahim, W. 2011. Effect of date seeds on oxidative damage and antioxidant status in vivo. J Sci Food Agric, 91(9), 1674-1679, https://doi. org/10.1002/JSFA.4368. 